\title{
MILAN POLIĆ - ODLAZAK UČITELJA
}

\author{
Boris Drandić
}

Profesor Milan Polić nije imao odgovor na svako pitanje, ali je imao pitanje za svaki odgovor.

Naši brojni i dugi razgovori s vremenom su poprimili ustaljeni obrazac. Nazvao bih ga radi neke sitnice, ponekad samo radi kakve fusnote u njegovom tekstu što sam ga uređivao, a potom bi razgovor krenuo sam od sebe kao niz asocijacija, pitanja, odgovora, komentara i dosjetaka. Ja bih pitao kao filozofska neznalica, a on bi odgovarao shvaćajući posve moj položaj, objašnjavajući mi odgovore i rješenja davno mrtvih filozofa i birajući one za koje se nadao kako ću ih moći shvatiti. Ne čudi stoga što bi Sokrat bio gotovo obvezan sudionik naših razgovora, Sokrat koji je tvrdio kako ne vrijedi pisati knjige jer knjigu ne možeš ništa pitati. Ja sam u profesoru Poliću imao upravo tu živu knjigu koju sam mogao do sita pitati. On je bio moj filozofski kompendij, zamjena za stotine izvornih filozofskih djela što ih nikad nisam pročitao, a bez njegovih strpljivih objašnjenja i suvremenih primjera ne bih dobio uvid u filozofske probleme u rasponu od par tisućljeća. Ipak, poput mog osobnog Sokrata, profesor Polić mi nikada nije nudio gotova rješenja i odgovore što sam ih trebao upamtiti. Svi njegovi odgovori bili su samo međukorak k novim pitanjima. Uostalom, i sam je znao reći kako u četrdeset godina filozofiranja nije stekao osjećaj da je nekim odgovorima bliže nego kad je počeo. Stoga mi se čini kako je više strasti ulagao u pitanje sve pronicavijih pitanja, nego u odgovore što ih je smatrao samo pripremom za novo pitanje. Kao da su njegovo golemo znanje i erudicija služili prije svega osmišljavanju pitanja, često istih pitanja što su mučila filozofe stoljećima, ali ih je on oblikovao kao mislilac 21. stoljeća. Uz njega sam naučio kako filozof treba znati mnoge odgovore ako hoće pitati prava pitanja, ali i to da neispitan život nije vrijedan življenja. Zato je bio nesklon odgovorima što nisu sadržali nova pitanja.

To može objasniti njegov odnos prema religiji zbog čega se deklarirao u javnosti kao ireligiozna osoba, a nije imao ništa protiv ako ga 
zovu ateistom. Čini mi se kako mu je religija bila neprihvatljiva jer nudi previše odgovora, a dopušta tako malo pitanja. Često je javno diskutirao s katoličkim teolozima i intelektualcima, ali bi iznimno naišao na dostojnog sugovornika jednako sklonog pitanjima i istraživanju. Zato mi je drago što je upravo na stranicama našeg Nastavničkog suputnika 2014./15. diskutirao s don Antonom Šuljićem o pitanjima hrvatske kulture, pobačaja i eutanazije i što sam, zajedno s našim čitateljima, imao čast pratiti dva majstora rasprave na djelu. Zapravo, prof. Polić nije bio uobičajeni ateist, onakav tko u svom misaonom životu goji samo jednu misao: »Nema boga, nema boga! Je li da nema Boga?« On je otvoreno vjerovao u mogućnost neke više stvarnosti što nadilazi naše iskustvo $i$ sadašnje poimanje, tamo negdje iznad i izvan religije kao ljudske djelatnosti, stvarnosti o kojoj ne zna ništa jer ne zna kako bi o njoj valjano pitao.

I njegovo promišljanje filozofije odraz je strasti prema upitanosti. Smatrao je kako svako dosljedno filozofiranje mora na koncu završiti u solipsizmu, toj crnoj rupi mišljenja gdje se zbilja ukida u nemogućnosti potvrde postojanja svijeta oko nas i drugih umova. Ostaje samo besmisleni »cogito ergo sum«, pojedinačni um svjestan svog postojanja, ali usamljen jer je jedini stvaran. Profesor Polić je držao kako svaka prava filozofija bira zastati korak do ponora solipsizma izbjegavajući time pad u ništavilo, kraj filozofije i konac svakog smislenog pitanja. On je odabrao usprotiviti se ponoru ljubavlju i tako se vratiti čovjeku te otvoriti posve nova pitanja iz perspektive onoga koji je vidio kraj svijeta i sretno se vratio među ljude. Nije mi to rekao ovim riječima, ali kad bih želio sažeti njegovo uvjerenje, čini mi se da bi parafraza znamenite Marxove misli bila najbliža: »Filozofi su samo različito tumačili svijet, a stvar je u tome da se on zavoli!«

Možda je najvažniji primjer njegovo određenje samoga sebe, zapravo nedostatak tog određenja. Da, on je prihvaćao činjenicu da je još uvijek zaljubljeni suprug, odgovoran otac, dosljedan profesor i odgajatelj mladih, upitani filozof, ireligiozan po vlastitom izboru, ateist po potrebi, zaigrani umjetnik i jasan pisac te na koncu strastveni humanist, ali je sve to smatrao provizornim i nepreciznim oznakama i često tvrdio kako to još uvijek nije potpuni Milan Polić. On nije želio sebe odrediti u obliku konačnog odgovora jer je smatrao kako se čovjek iznova definira dokle god živi pa je nemoguće o sebi reći išta određenog i posljednjeg dok život traje. On je svoj život smatrao projektom i nadao se 
kako će ga smrt presjeći usred tog projekta, usred poslova, tekstova što ih valja napisati - usred posljednjeg pitanja. Dva dana prije smrti i dan prije operacije razgovarali smo kao obično, on je po običaju bio strpljivi učitelj, društvo su nam bili filozofi što ih je njegovo pripovijedanje tako slikovito znalo oživjeti i pretvoriti u sugovornike. Izložio mi je što želi učiniti za trajanja oporavka, s radošću je govorio o tekstovima što će ih pisati i već je imao zamisao o članku za novi Znamenov Nastavnički suputnik. Osjećao sam kako jedva čeka otpust iz bolnice jer ima ljepšeg posla nego tu ležati. Još mi je kazao: »Bit ću zadovoljan ako na koncu vratim $60 \%$ prijašnje snage. To će mi biti dovoljno za projekte što ih planiram ostvariti.« Od ovoga se svijeta oprostio upravo kako je želio.

Prvi put sam doista osjetio da profesora Polića više nema kad sam se mučio jednim teškim pitanjem i poželio sam ga upitati za mišljenje i komentar. Gotovo sam glasno zaustio pitanje, a odgovorila mi je samo mukla tišina. S mjesta gdje je trebao biti živi i duhoviti lik, u mene je netremice gledala crna praznina, strašna konačnost. Misao na vječnost je tako ukorijenjena u našoj podsvijesti da nas svaki put iznenadi kad nam njen komad bude otrgnut i nepovratno uzet. Možda tek veličina i dubina te crnine najjasnije ukazuje koliko smo svjetlosti izgubili odlaskom Milana Polića. Ja sam izgubio učitelja filozofije i života, jednog od onih ljudi za čije brojanje su dovoljni prsti jedne ruke. Nismo proveli mnogo vremena zajedno i uglavnom smo razgovarali telefonom, ali njegove misli, dosljednost, snaga uvjerenja, tolerantnost, strpljenje i uviđavnost, strast za istraživanjem i propitivanjem svega, ostaju u meni kao da su za nama godine druženja uz sir, pršut i vino.

Tko je i što je bio Milan Polić, što je značio svakome od nas, po čemu je ovaj svijet bolji nakon njega, a zašto smo bolji mi koji smo imali zadovoljstvo i čast, pa ako hoćete i milost, podijeliti s njim nešto njegovog vremena - pitanja su što će nas dugo zaokupljati i nastaviti oblikovati naše živote dok se budemo trudili žižak ljubavi što nam ga je predao sačuvati od ledenih kandža bešćutnog svemira. 